\title{
Simulated runoff responses to land use in the middle and upstream reaches of Taoerhe River basin, Northeast China, in wet, average and dry years
}

\author{
Lijuan $\mathrm{Li}^{1}{ }^{1}$ Dejuan Jiang, ${ }^{2 *}$ Xiyong $\mathrm{Hou}^{2}$ and Jiuyi $\mathrm{Li}^{1}$ \\ ${ }^{1}$ Institute of Geographic Sciences and Natural Resources Research, Chinese Academy of Sciences, Beijing 100101, China \\ ${ }^{2}$ Yantai Institute of Coastal Zone Research, Chinese Academy of Sciences, Yantai 264003, China
}

\begin{abstract}
:
Study on runoff variations and responses can lay a foundation for flood control, water allocation and integrated river basin management. This study applied the Soil and Water Assessment Tool model to simulate the effects of land use on annual and monthly runoff in the Middle and Upstream Reaches of Taoerhe River basin, Northeast China, under the wet, average and dry climate conditions through scenario analysis. The results showed that from the early 1970s to 2000, land use change with an increase in farmland (17.0\%) and decreases in forest (10.6\%), grassland (4.6\%) and water body (3.1\%) caused increases in annual and monthly runoff. This effect was more distinct in the wet season or in the wet year, suggesting that land use change from the early 1970s to 2000 may increase the flood potential in the wet season. Increases in precipitation and air temperature from the average to wet year led to annual and monthly (March and from June to December) runoff increases, while a decrease in precipitation and an increase in air temperature from the average to dry year induced decreases in annual and monthly (all months except March) runoff, and moreover, these effects were more remarkable in the wet season than those in the dry season. Due to the integrated effects of changing land use and climate conditions, the annual runoff increased (decreased) by $70.1 \mathrm{~mm}(25.2 \mathrm{~mm})$ or $197.4 \%(71.0 \%)$ from the average to wet (dry) year. In conclusion, climate conditions, especially precipitation, played an important role in runoff variations while land use change was secondary over the study area, and furthermore, the effects of changes in land use and/or climate conditions on monthly runoff were larger in the wet season. Copyright (C) 2012 John Wiley \& Sons, Ltd.
\end{abstract}

KEY WORDS runoff; land use change; climate conditions; precipitation; SWAT

Received 22 April 2010; Accepted 4 July 2012

\section{INTRODUCTION}

Water resources and hydrological cycle in river basins are altered by climate change and human activities (Vörösmarty et al., 2000; Wang et al., 2007; Kundzewicz et al., 2007; Guo et al., 2008; Ma et al., 2009). Climate change affects the distribution and variation of regional precipitation and air temperature, and hence affects catchment runoff (Wang et al., 2008). To the utmost extent, climate condition, particularly precipitation, is the key factor to determine runoff characteristics (Liu, 2004). However, in past decades, human activities have dramatically changed hydrological processes by drawing water from rivers or underground in order to provide water for agriculture, industry and domestic sectors, by water conservancy construction such as inter-basin water transfer, dam/reservoir construction, and by land use change indirectly. Land use change, which is an important aspect of global environment change and in a sense, is the direct result of human activities influencing the physical environment (Liu et al., 2002), alters the characteristics of underlying surface and subsequently runoff generation

*Correspondence to: Dejuan Jiang, Yantai Institute of Coastal Zone Research, Chinese Academy of Sciences, Chunhui road 17\#, Laishan District, Yantai, Shandong, China, 264003.

E-mail: djjiang@yic.ac.cn and hydrological cycle by such means as afforestation and deforestation, water and soil conservation, agriculture development, urbanization and so on (Wegehenkel, 2002; Crokea et al., 2004; Li et al., 2007). Important work has been carried out on hydrological response to land use and/ or climate changes (e.g. Fohrer et al., 2001; Niehoff et al., 2002; Legesse et al., 2003; Costa et al., 2003; DeFries and Eshleman, 2004; Singh and Bengtsson, 2004; Crokea et al., 2004; Bewket and Sterk, 2005; Romanowicz et al., 2005; Chaves et al., 2008; Li et al., 2009; Ma et al., 2009), which revealed some interrelationship of land use and/or climate changes with various aspects of regional hydrological cycle (Guo et al., 2008). For example, Bewket and Sterk (2005) showed that land use changes with destruction of natural vegetative covers, expansion of croplands, overgrazing and increased area under eucalypt plantations caused an increase in transpiration losses and a decline in base flow. Legesse et al. (2003) found that over Tropical Africa, the change in discharge was more sensitive to climate change than to land use change. Ma et al. (2009) showed that the impact of climate change on surface water, baseflow and streamflow was offset by the impact of land cover change.

In the 20th century, especially since 1990s, many international organizations such as IHP, WCRP, IGBP and GWSP have implemented a series of water-related projects, which objective is to study hydrological cycle 
and linked resources and environmental problems caused by global change and human activities at the global, regional and catchment scales (Xia and Tan, 2002). Their research results show that for a long time, climate change has more remarkable impacts on hydrological variations while in the short time, land use change is one dominant influencing factor (Vörösmarty et al., 2000). However, the rainfall characteristics, such as volume, duration, intensity and the antecedent soil moisture conditions, have a great influence on the hydrological response to land use change (Shi et al., 2001; Niehoff et al., 2002; Liu et al., 2006). For example, if the rainfall intensity is high and the surface has a rather small conductivity, runoff generation may be considerably controlled by the landcover or soil-surface conditions (Niehoff et al., 2002). Therefore, it is of great difficulty to quantitatively distinguish their individual contributions for hydrological variations because the effects of land use and climate changes on hydrological processes are interacted. Fortunately, the distributed hydrological model can be employed as an effective tool to simulate runoff scenarios under changing land use and climate conditions and hence, predict the hydrological response to land use and climate changes (Fohrer et al., 2001; Haverkamp et al., 2005). In the simulations, land use parameters are changed with constant meteorological forcing; inversely, meteorological parameters are changed with constant land use parameters. In this way, the effects of land use and climate changes on hydrology can be isolated from each other.

In recent years, the Soil and Water Assessment Tool (SWAT) model has been widely used on different varieties and sizes of catchments in many countries of the world and has been proved as an effective tool to predict the consequences of land use and/or climate changes on hydrological variations (e.g. Muttiah and Wurbs, 2002; Pohlert et al., 2005; Wu and Johnston, 2007; Lee and Chung, 2007; Guo et al., 2008; Ma et al., 2009). In this study, the SWAT model was used to simulate the impacts of land use change on annual and monthly runoff in the middle and upstream reaches of Taoerhe River basin, Northeast China, in the wet, average and dry years.

\section{MATERIALS AND METHODS}

\section{Description of the study area}

Taoerhe River originates in the Daxing'anling Mountain, and it is located in western Songnen Plain at a latitude of $45^{\circ} \mathrm{N}-47^{\circ} \mathrm{N}$ and a longitude of $120^{\circ} \mathrm{E}-124^{\circ} \mathrm{E}$. The river with a total drainage area of about $33070 \mathrm{~km}^{2}$, primarily flows from west to east and at last, enters Nenjiang River (Figure 1). From the southeast to the northwest of the catchment, the climate varies from semi-arid to semi-humid condition, the relief varies from plain to mountain, vegetation varies from grain crops to grass and then to forest. For recent decades, under the increasing stress from human activities and climate changes, the ecosystem and environment has being suffering from serious destruction and deterioration, such as river drying up, wetland shrink, secondary salinization and water pollution. Therefore, the eco-environment of Taoerhe River basin is very fragile and sensitive, which is deemed as an epitome of the west of Northeast China.

The middle and upstream reaches of Taoerhe River basin was selected for this study, covering an area of $27633 \mathrm{~km}^{2}$ (Figure 1). The elevation over the study area varies from $250 \mathrm{~m}$ in the southeast to $1700 \mathrm{~m}$ in the northwest. The study area is characterized by the temperate continental monsoon climate. The mean annual precipitation varies between $279 \mathrm{~mm}$ and $749 \mathrm{~mm}$ with an average of about $427 \mathrm{~mm}$ and more than $80 \%$ of annual precipitation occurs in the wet season (from June to September) while less than $20 \%$ falls in the dry season (from October to May). The mean annual observed runoff measured at the outlet of the study area, Taonan hydrological station, is approximately $38.2 \mathrm{~m}^{3} / \mathrm{s}$. The runoff variability within the year is characterized by the remarkable high and low flow season due to the seasonal difference of precipitation, and there is one-month lag between the wet season and high flow season. The mean annual air temperature ranges from $3.6^{\circ} \mathrm{C}$ in 1969 to $6.8^{\circ} \mathrm{C}$ in 1998 with an average of about $5.5^{\circ} \mathrm{C}$. The frostless period varies from 130 days to 140 days, and the frozen soil depth is about $2 \mathrm{~m}$. The present vegetation cover is mostly composed by Larix gmelinii, Scotch Pine, Betula platyphylla, Picea jezoensis, Aneurolepidium Chinense, Stipa baicalensis and grain crops. The main soil types are dark brown soil, meadow soil, dark chestnut soil, chernozem, which areas account for $86 \%$ of the study area.

\section{SWAT model}

The SWAT model has been developed by US Department of Agriculture - Agriculture Research Service (USDA-ARS) based on the concept of Simulator for Water Resources in Rural Basins. The model is a distributed process-based hydrological model and operates continuously on a daily time step. It is developed to predict the impact of land management practices on water, sediment and agricultural chemical yields in large and complex catchments with varying soils and land use and management conditions over long periods of time.

The SWAT model is based on the water balance in the soil profile, and the processes simulated include infiltration, surface runoff, evapotranspiration (ET), lateral flow and percolation. In the SWAT model, the water balance equation (Arnold et al., 1998) is expressed as:

$$
S W_{t}=S W_{0}+\sum_{i=1}^{t}\left(R_{\text {day }}-Q_{\text {surf }}-E_{a}-W_{\text {seep }}-Q_{g w}\right)
$$

where $S W_{t}$ is the final soil water content $(\mathrm{mm}), S W_{O}$ is the initial soil water content $(\mathrm{mm}), i$ is time in days for the simulation period $t, R_{\text {day }}, Q_{\text {surf }}, E_{a}, W_{\text {seep }}$ and $Q_{g w}$ are respectively the amount of precipitation, surface runoff, ET, percolation and return flow on day $i$. 




Figure 1. Range and location map of the study area

In this study, surface runoff was estimated by the SCS curve number method based on daily precipitation records. In terms of the SWAT simulation accuracy over the study area, Priestley and Taylor equations were chosen for simulation of potential ET, and the Muskingum method was used for channel water routing.

\section{Data}

Spatial data used in this study included a digital elevation model (DEM), land use data and soil type data. DEM at the resolution of 1:250 000 was derived from National Geomatics Center of China. Three land use conditions were used in this study: land use map of the early 1970s which was interpreted based on topographic map and Land TM images by us, land use maps of 1990 and 2000 which were provided by Data Center for
Resources and Environmental Sciences, Chinese Academy of Sciences (CAS) and was interpreted based on Landsat TM images. The land use types can be categorized into paddy land, dry land, forest, grassland, water body, constructed land and saline land (Table I). Soil type data with a scale of 1:1000 000 was obtained from Institute of Soil Science, CAS (Shi et al., 2002).

For simulating runoff, the following databases needed to be established to represent local conditions: meteorological data, land use property data and soil property data. Meteorological data included daily precipitation, maximum and minimum air temperature, relative humidity, wind speed, solar radiation, which were obtained from the National Climate Center of China, China Meteorological Administration. There were five meteorological stations with long-term records during 1961-2001: Baicheng, Wulanhaote, Suolun, Tailai and A'ershan (Table II), but 
Table I. The classification system and definitions of land use types in this study

\begin{tabular}{lll}
\hline ID & \multicolumn{1}{c}{ Name } & \multicolumn{1}{c}{ Description } \\
\hline 1 & Paddy land & Farmlands with water resource guarantee and irrigating facilities using for rice growing \\
2 & Dry land & Lands for cultivating without irrigating facilities; dry croplands and lands growing vegetables \\
3 & Forest & Lands growing trees including arbor, shrub, bamboo and lands for forestry use \\
4 & Grassland & $\begin{array}{l}\text { Lands covered by herbaceous plant with coverage grater than 5\%, including shrub-grass for } \\
\text { pasture and the woods with cover canopies less than 10\% } \\
\text { Lands covered by natural water bodies or lands with facilities for irrigation and water } \\
\text { reservation, including wetlands }\end{array}$ \\
5 & Water body & Lands used for urban and rural settlements and factories and transportation facilities \\
6 & Constructed land & Lands with saline accumulation and sparse vegetation \\
\hline
\end{tabular}

Table II. List of meteorological or rain-gauge stations used in this study

\begin{tabular}{lrcr}
\hline Name & Longitude $\left({ }^{\circ} \mathrm{E}\right)$ & Latitude $\left({ }^{\circ} \mathrm{N}\right)$ & Elevation $(\mathrm{m})$ \\
\hline Baicheng $^{*}$ & 122.80 & 45.63 & 155 \\
Wulanhaote $^{*}$ & 122.05 & 46.08 & 275 \\
Suolun $^{*}$ & 121.22 & 46.60 & 5502 \\
Tailai $^{*}$ & 123.42 & 46.4 & 150 \\
A'ershan $^{*}$ & 119.95 & 47.17 & 1027 \\
Taonan $^{\dagger}$ & 122.90 & 45.37 & 154 \\
Wuben $^{\dagger}$ & 122.32 & 45.65 & 189 \\
Zhenxi $^{\dagger}$ & 122.37 & 45.85 & 243 \\
Gaojiatun $^{\dagger}$ & 121.60 & 45.62 & 300 \\
Chaersen $^{\dagger}$ & 121.90 & 46.32 & 350 \\
Dashizhai $^{\dagger}$ & 121.35 & 46.28 & 450 \\
\hline
\end{tabular}

Note: ${ }^{*}$, was meteorological station and "†, was rain-gauge station.

two stations of Tailai and A'ershan lie outside the study area. In addition, rainfall data of six rain-gauge stations, Chaersen, Dashizhai, Gaojiatun, Taonan, Zhenxi, Wuben, were also used for runoff simulation, which were available from Songliao River Water Resources Commission (Table II). Land use property data was obtained from land use map. Soil property database was established based on the China soil database and a soil correlation system combined with soil water characteristics software: SPAW developed by Agricultural Research Service, USA (http://www.ars.usda.gov/ba/anri/hrsl).

Runoff data at Taonan Hydrological Station, covering the period from 1961 to 2001 at the annual and monthly time steps were used for comparisons against the simulated runoff in the model calibration and validation, which were gained from Songliao River Water Resources Commission. Runoff amount which were diverted for agriculture, industry and domestic water use or were impounded by dams or reservoirs, i.e. water abstraction (Figure 2), have been returned back to the observed runoff data by Songliao River Water Resources Commission and hence, these runoff data was the corrected runoff data with assumption of no water abstractions. Consequently, the accuracy to quantitatively evaluate the runoff responses to land use change in wet, average and dry years could be greatly improved or guaranteed.

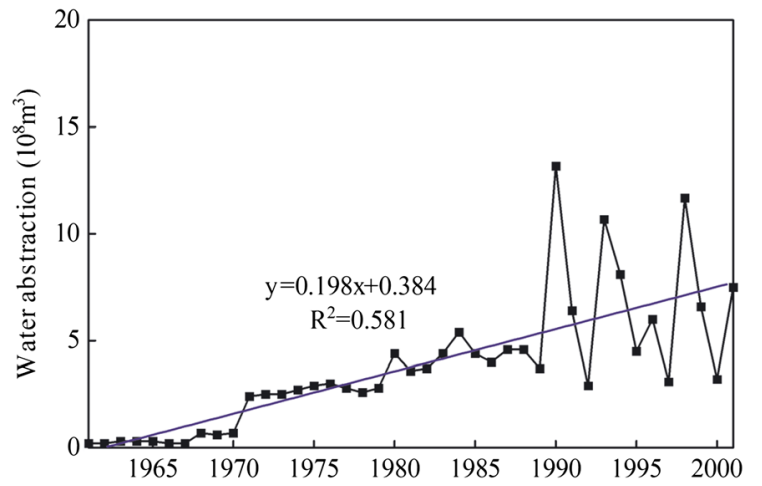

Figure 2. Water abstraction from the Taoerhe River during 1961-2001

\section{Delineation of sub-basins and HRUs}

Spatially, the SWAT model divided a catchment into sub-basins based on topographic information. The sub-basins could further be classified into smaller spatial modelling units known as Hydrologic Response Units (HRUs) depending on the heterogeneity of land use and soil types within the sub-basins (Arnold and Fohrer, 2005). Using a $100 \times 100 \mathrm{~m} \mathrm{DEM}$, the study area was divided into 49 sub-basins and further 279 HRUs. Characteristics of sub-basins and HRUs were calculated and used in the SWAT simulations.

\section{Model calibration and validation}

The available runoff data were divided into two segments: a calibration period (1963-1975) with land use map of the early 1970s and a validation period (1986-2001) with land use map of 2000 for the modeling analyses with a model initialization period set to 1961-1962. The interval of 1976-1985 was discarded to allow for a larger difference in land use between the two periods. The calibration and validation was carried out by comparing the SWAT simulated values with the corrected runoff values on annual and monthly basis until satisfactory results were obtained (Santhi et al., 2001; Albek et al., 2004; Lee and Chung, 2007; Ma et al., 2009).

The Nash-Sutcliffe model efficiency $\left(E_{n s}\right)$, percent bias $(P B I A S)$ and ratio of the root mean square error (RMSE) to the standard deviation of measured data $(R S R)$ were used to 
assess the model's prediction capability (Moriasi et al., 2007). $E_{n s}$ indicates how well the plot of observed versus simulated data fits the 1:1 line: the performance is perfect if $E_{n s}=1$. PBIAS measures the average tendency of the simulated data to be larger or smaller than their observed counterparts: the optimal value of $P B I A S$ is 0.0 , with low-magnitude values indicating accurate model simulation. $R S R$ standardizes $R M S E$ using the observed standard deviation: the lower $R S R$ is, the better the performance of the model simulation. The equations for $E_{n s}, P B I A S$ and $R S R$ were given as follows:

$$
\begin{gathered}
E_{n s}=1-\frac{\sum_{i=1}^{n}\left(Q_{i}^{\text {obs }}-Q_{i}^{\text {sim }}\right)^{2}}{\sum_{i=1}^{n}\left(Q_{i}^{\text {obs }}-Q^{\text {mean }}\right)^{2}} \\
\text { PBIAS }=\frac{\sum_{i=1}^{n}\left(Q_{i}^{\text {obs }}-Q_{i}^{\text {sim }}\right) \times 100}{\sum_{i=1}^{n} Q_{i}^{\text {obs }}} \\
R S R=\frac{R M S E}{S T D E V_{\text {obs }}}=\frac{\sqrt{\sum_{i=1}^{n}\left(Q_{i}^{\text {obs }}-Q_{i}^{\text {sim }}\right)^{2}}}{\sqrt{\sum_{i=1}^{n}\left(Q_{i}^{\text {obs }}-Q^{\text {mean }}\right)^{2}}}
\end{gathered}
$$

where $Q_{i}^{o b s}$ is the $i$ th observed value for the constituent being evaluated, $Q_{i}^{\text {sim }}$ is the $i$ th simulated value for the constituent being evaluated, $Q^{\text {mean }}$ is the mean of observed data for the constituent being evaluated and $n$ is the total number of observations.

\section{Evaluating the impacts of changing land use and climate conditions on runoff}

For this study, land use maps of the early 1970s, 1990 and 2000 were used to present land cover conditions. Climate conditions were described by the averaged conditions and by the extremely wet and dry conditions during the study period. In order to correspond to the periods of land use conditions, $1970(P=50 \%), 1990(P=2.5 \%)$ and 2001 $(P=97.5 \%)$ were selected to represent the average, wet and dry years, respectively. To reveal the effects of land use change on runoff in three precipitation years, several scenarios were considered as follows: the combination of the land use map for the early 1970s, respectively, with the climate data for 1970, 1990 and 2001 (i.e. simulation 1, 2, 3 ), the land use map for 1990, respectively, with the climate data for 1970, 1990 and 2001 (i.e. simulation 4, 5, 6), the land use map for 2001, respectively, with the climate data for 1970, 1990 and 2001 (i.e. simulation 7, 8, 9) (Table III). The difference between the SWAT outputs of simulation 1 and simulation 2 or 3 was attempted to reveal the impacts of changing climate conditions on runoff under the early 1970 s land use conditions, simulation 4 and simulation 5 or 6 was attempted to reveal the impacts of changing climate conditions on runoff under 1990 land use conditions, simulation 7 and simulation 8 or 9 was attempted to reveal
Table III. Scenarios for evaluating the impacts of changing land use and climate conditions on runoff

\begin{tabular}{ll}
\hline No. & \multicolumn{1}{c}{ Scenarios } \\
\hline S1 & the early 1970s land use and 1970 climate \\
S2 & the early 1970s land use and 1990 climate \\
S3 & the early 1970s land use and 2001 climate \\
S4 & 1990 land use and 1970 climate \\
S5 & 1990 land use and 1990 climate \\
S6 & 1990 land use and 2001 climate \\
S7 & 2000 land use and 1970 climate \\
S8 & 2000 land use and 1990 climate \\
S9 & 2000 land use and 2001 climate \\
\hline
\end{tabular}

the impacts of changing climate conditions on runoff under 2000 land use conditions, simulation 1 and simulation 4 or 7 was used to depict the impacts of land use change on runoff for the average year, simulation 2 and simulation 5 or 8 was to depict the impacts of land use change on runoff for the wet year and simulation 3 and simulation 6 or 9 was to depict the impacts of land use change on runoff for the dry year.

\section{RESULTS AND DISCUSSION}

\section{Land use changes}

Farmland including paddy and dry land, forest, grassland were the primary land use types in the early 1970s, 1990 and 2000 (Figure 3 and Table IV), which areas, respectively, accounted for $13.4 \%$ (accounting for the total study area), $36.3 \%$ and $43.1 \%$ in the early 1970 s, $25.5 \%, 33.8 \%$ and $35.4 \%$ in $1990,30.5 \%, 25.7 \%$ and $38.5 \%$ in 2000 . Spatially, most of the upper reaches were occupied by forest and grassland, while other land use types were mainly distributed in the middle reaches.

From the early 1970 s to 1990 , the most noticeable changes in land use were increases in farmland (12.1\%) while decreases in forest $(2.6 \%)$, grassland $(7.7 \%)$ and water body (3.0\%). From 1990 to 2000, the most remarkable changes in land use were increases in farmland $(5.1 \%)$ and grassland $(3.1 \%)$ while a decrease in forest $(8.1 \%)$.

From the early 1970 s to 2000 , land use changes were characterized by decreases in forest (10.6\%), grassland $(4.6 \%)$ and water body $(3.1 \%)$ but increases in farmland $(17.0 \%)$, constructed land $(0.5 \%)$ and saline land $(0.8 \%)$. Conversions from forest to grassland, from grassland to dry land, from grassland to forest, from forest to dry land, and from water body to dry land were the major land use change types, which areas accounted for $81.6 \%$ of the total area of all land use conversion types. These characteristics of land use changes suggested that the increasing intensity of human activities could drive the ecosystem towards deterioration.

\section{Changes in runoff, precipitation and air temperature}

The 41-year data analysis was carried out for the trends in annual runoff, precipitation and air temperature, and the non-parametric Mann-Kendall test (Sneyers, 1990) was used to detect the statistical significance of these trends at the 0.05 level (Figure 4). From 1961 to 2001, the annual runoff 

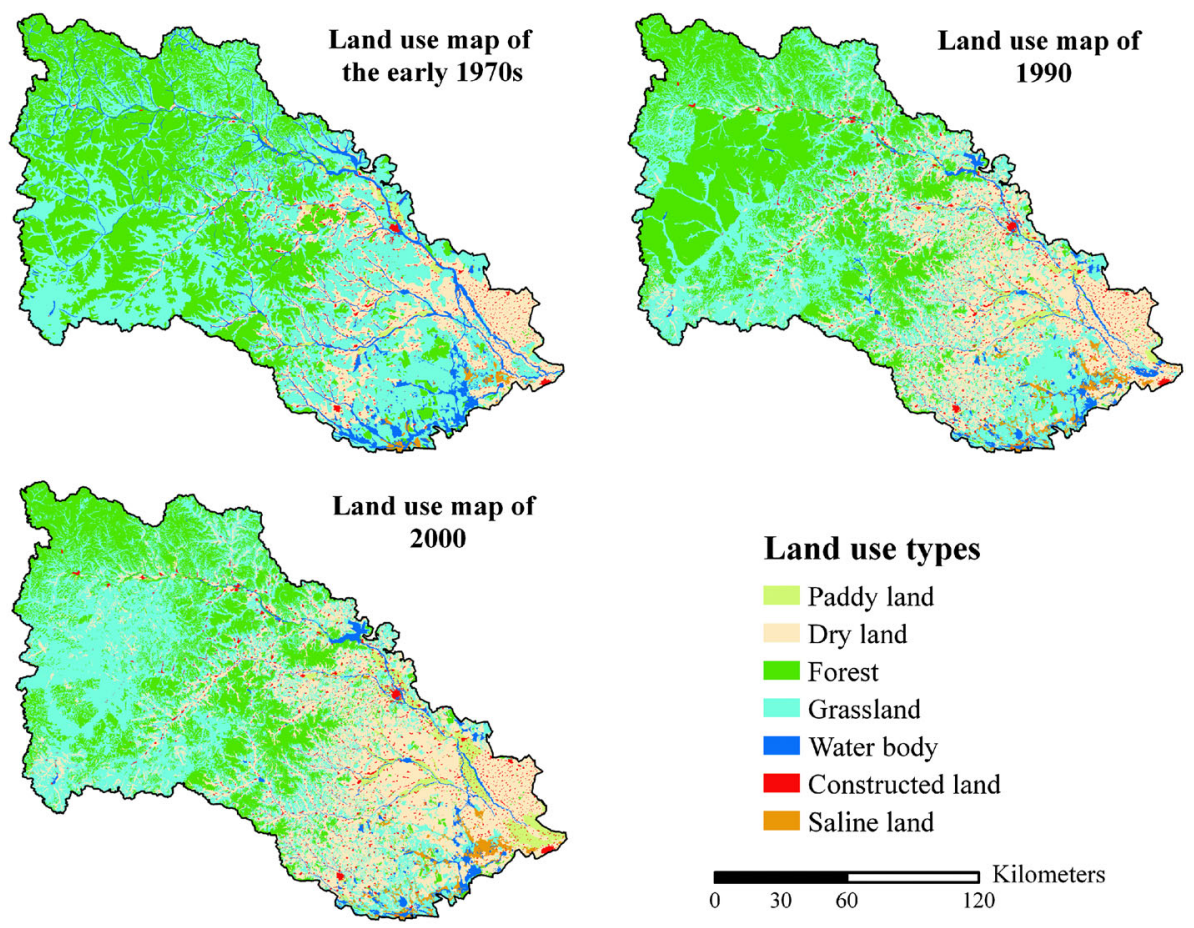

Figure 3. Land use maps in the early 1970s, 1990 and 2000

Table IV. Area change of land use types in the early 1970s, 1990 and 2000

\begin{tabular}{|c|c|c|c|c|c|c|}
\hline \multirow[b]{2}{*}{ Land use type } & \multicolumn{3}{|c|}{ Area $\left(\times 10^{4} \mathrm{hm}^{2}\right)$} & \multicolumn{3}{|c|}{ Area change of total area $(\%)$} \\
\hline & $1970 \mathrm{~s}$ & 1990 & 2000 & $1970 s-1990$ & 1990-2000 & $1970 s-2000$ \\
\hline Paddy land & 1.9 & 2.9 & 7.5 & 0.4 & 1.7 & 2 \\
\hline Dry land & 35.2 & 67.5 & 76.7 & 11.7 & 3.4 & 15 \\
\hline Forest & 100.4 & 93.3 & 71 & -2.6 & -8.1 & -10.6 \\
\hline Grassland & 119 & 97.7 & 106.4 & -7.7 & 3.1 & -4.6 \\
\hline Water body & 14.6 & 6.4 & 6 & -3 & -0.2 & -3.1 \\
\hline Constructed land & 4 & 5.4 & 5.4 & 0.5 & 0 & 0.5 \\
\hline Saline land & 1.2 & 3.1 & 3.3 & 0.7 & 0.1 & 0.8 \\
\hline
\end{tabular}



Figure 4. Annual trend of corrected runoff, precipitation and air temperature during 1961-2001

showed a significant increasing trend, which was characterized by a strong inter-annual variability and a great uneven distribution of the year. The annual precipitation had a rising trend, and however, this trend was not significant.
The annual air temperature indicated a significant increase, particularly since 1990s, when the annual mean air temperature was about $1{ }^{\circ} \mathrm{C}$ higher than before 1990 .

In addition, the monotonic trends for monthly runoff and precipitation during 1961-2001 were analyzed using the non-parametric Mann-Kendall test. The results (Table V) showed that for monthly runoff, there was a decreasing trend in January, February, October, November and December, and there was an increasing trend in other months; however, these trends were significant in March, June and July at the 0.1 level. Monthly precipitation had a long-term monotonic trend only in December, and it was not significant in other months.

\section{Model calibration and validation}

Eight most sensitive parameters were calibrated based on their control on runoff, consisting of $C N 2$, ESCO, $S O L \_A W C, G W \_R E V A P, G W \_A L P H A, \quad R E V A P M N$, $S M F M X$ and SMFMN. CN2 and ESCO were the most two sensitive parameters, because $C N 2$ values affected the peak subsurface drain flow while ESCO inputs affected the 
Table V. Mann-Kendall test statistic for monthly runoff and precipitation during 1961-2001

\begin{tabular}{|c|c|c|c|c|c|c|}
\hline \multirow[b]{2}{*}{ Month } & \multicolumn{3}{|c|}{ Monthly runoff } & \multicolumn{3}{|c|}{ Monthly precipitation } \\
\hline & $Z$ & $\beta$ & $P$ & $Z$ & $\beta$ & $P$ \\
\hline Jan & -0.483 & 0.000 & & 0.079 & 0.001 & \\
\hline Feb & -0.517 & 0.000 & & -0.371 & -0.004 & \\
\hline Mar & 2.505 & 0.010 & $* *$ & 1.629 & 0.058 & \\
\hline Apr & 0.135 & 0.003 & & 0.416 & 0.045 & \\
\hline May & 1.483 & 0.042 & & 0.371 & 0.077 & \\
\hline Jun & 2.359 & 0.120 & $* *$ & 1.112 & 0.570 & \\
\hline Jul & 1.865 & 0.196 & $*$ & -0.618 & -0.559 & \\
\hline Aug & 1.618 & 0.119 & & -0.618 & -0.347 & \\
\hline Sep & 0.696 & 0.047 & & 0.663 & 0.227 & \\
\hline Oct & -0.258 & -0.009 & & 0.461 & 0.093 & \\
\hline Nov & -1.348 & -0.016 & & 0.595 & 0.021 & \\
\hline Dec & -1.505 & -0.004 & & 1.786 & 0.031 & $*$ \\
\hline
\end{tabular}

Note: '*' meant significant at $P<0.1$ and '**' meant significant at $P<0.05$.

shape of the subsurface drain flow hydrograph. Table VI showed the calibrated model parameter values together with the locally estimated parameters.

Figure 5 showed the corrected and simulated annual runoff in the calibration and validation period. During the calibration period, $E_{n s}, P B I A S$ and $R S R$ were $0.66,5.0 \%$ and 0.59 , respectively, indicating that there was a good agreement between the corrected and simulated annual runoff (Moriasi et al., 2007). During the validation period, $E_{n s}, P B I A S$ and $R S R$ were $0.83,9.1 \%$ and 0.41 , respectively, indicating that SWAT performance was very good according to Moriasi et al. (2007). However, we found that there was a great difference between them in some years such as 1969, 1986 and 1994, which may be caused by less meteorological stations or rain-gauge stations and their uneven distribution over the study area as well as the absence of the time series of rainfall data in some rain-gauge stations. In addition, the frequency and intensity of precipitation as well as the cultivation and management means of farmland could also have significant influences on runoff yield.

Figure 6 showed the comparison between the corrected and simulated monthly runoff. $E_{n s}, P B I A S$ and $R S R$ during the calibration period were $0.52,5.1 \%$ and 0.70 , respectively, indicating SWAT performance was

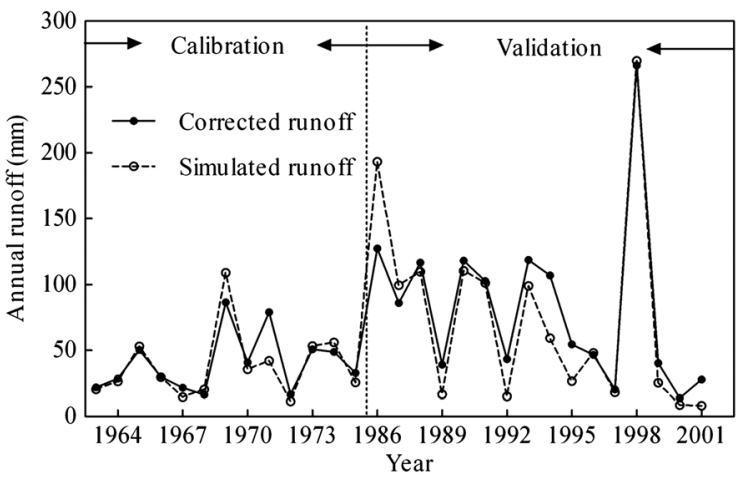

Figure 5. Corrected and simulated annual runoff for the calibration period and the validation period
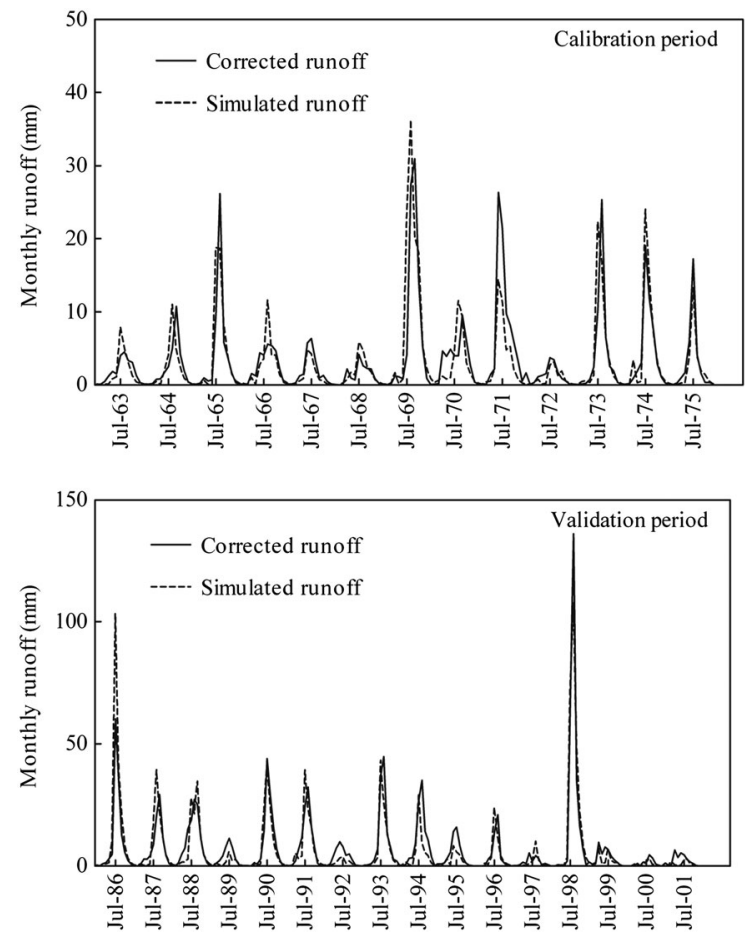

Figure 6. Corrected and simulated monthly runoff for the calibration period and the validation period

satisfactory according to Moriasi et al. (2007). $E_{n s}, P B I A S$ and $R S R$ during the validation period were $0.73,8.9 \%$ and 0.52 , respectively, showing that SWAT performance was

Table VI. Calibrated values of model parameters for the SWAT model

\begin{tabular}{|c|c|c|c|}
\hline Variable & Connotation & Range & Calibrated value \\
\hline CN2 & Condition II runoff curve number & $-8-+8$ & +4 \\
\hline$S O L \_A W C$ & Available water capacity of the soil layer & $-0.05-+0.05$ & +0.002 \\
\hline ESCO & Soil evaporation compensation coefficient & $0.00-1.00$ & 0.8 \\
\hline$G W \_R E V A P$ & Groundwater 'revap' coefficient & $0.02-0.20$ & 0.02 \\
\hline$G W_{-} A L P H A$ & Baseflow recession constant & $0.00-1.00$ & 0.023 \\
\hline$R E \overline{V A P M N}$ & $\begin{array}{l}\text { Threshold depth of water in the shallow aquifer for } \\
\text { 'revap' or percolation to the deep aquifer to occur }\end{array}$ & $0.00-500.00$ & 300 \\
\hline SMFMX & Melt factor for snow on June 21 & - & 1.00 \\
\hline$S M F M N$ & Melt factor for snow on December 21 & - & 1.00 \\
\hline
\end{tabular}


good (Moriasi et al., 2007). In general, the SWAT model was considered as an effective model for annual and monthly runoff simulation over the study area.

\section{Effects of land use change on runoff}

The effects of land use change on runoff differed in three precipitation years. In the average year, land use change from the early 1970 s to 1990 , from 1990 to 2000 and from the early 1970 s to 2000 , respectively, caused the annual runoff increase of $3.4 \mathrm{~mm}(9.6 \%), 1.8 \mathrm{~mm}(5.1 \%)$ and $5.2 \mathrm{~mm}(14.6 \%)$ (Table VII). In the wet year, land use change under the above three changing periods, respectively, increased the annual runoff by $12.6 \mathrm{~mm}(13.5 \%), 5.1 \mathrm{~mm}$ $(5.5 \%)$ and $17.7 \mathrm{~mm}(19.0 \%)$, while in the dry year, land use change caused an increase in annual runoff of $1.2 \mathrm{~mm}$ (13.5\%), $0.5 \mathrm{~mm}(5.2 \%)$ and $1.6 \mathrm{~mm}(18.6 \%)$, respectively. The increase of annual runoff may be attributed to the fact that the major change in land use with increase of farmland and decrease of forest, grassland and water body led to a lower rate of water loss by large reduction in ET. In comparison with land use change impacts among three precipitation years, the annual runoff increase in the wet year was much higher than that in the average or dry year, which could be explained by larger increase of surface runoff in the wet year. However, there was only a slight difference in the proportion of annual runoff variations, because in the wet year, abundant precipitation also provided more available water for ET.

Figure 7 indicated monthly runoff variations following land use change from the early 1970s to 2000 in three precipitation years. From the early 1970s to 2000, land use change, which had a great decrease of forest, grassland and water body as well as a large increase of farmland, caused monthly runoff increase at the majority of 12 months. The larger increase was found in the wet season, while a relatively small increase or decrease occurred in the dry season. The stronger effects on monthly runoff increase in the wet season may be due to high rainfall intensity but low soil moisture storage capacity following land use change, despite the increase in ET. The large increase of surface runoff was the major contributor for monthly runoff increase in this season. However, return flow and lateral flow had a small contribution, and even they had a small negative impact on monthly runoff increase. Therefore, the change in land use may increase the flood potential in the wet season. In the dry season, scarce rainfall and low temperature caused a small change in ET resulting from land use change, and consequently, the increase or decrease of monthly runoff was relatively small.

\section{Runoff variations due to different climate conditions}

Seen from Table VII and Figures 8, 9, annual and monthly runoff variations (proportion) from the average to wet/dry year were similar under three land use conditions. Therefore, the runoff variations due to different climate conditions were analyzed only under the land use condition of the early 1970s. From the

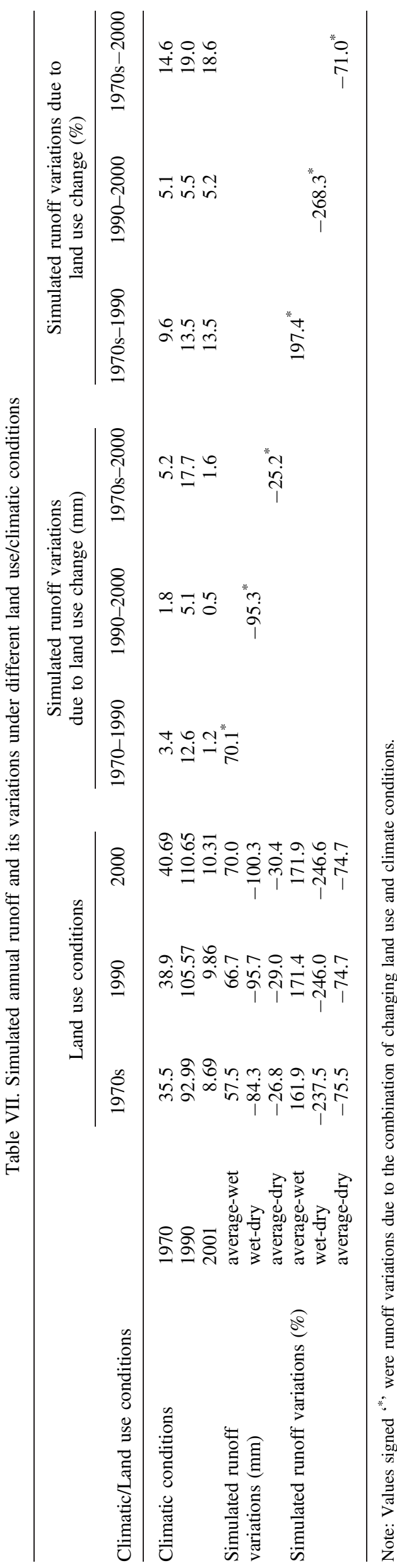




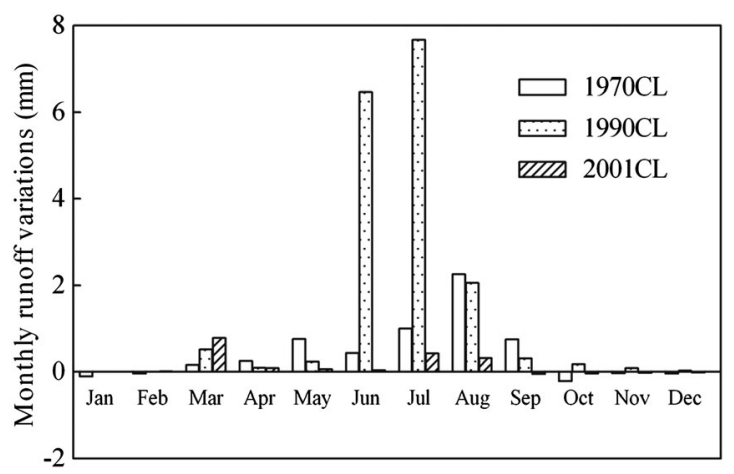

Figure 7. Monthly runoff variations due to land use change (the early 1970s to 2000) in different climate conditions

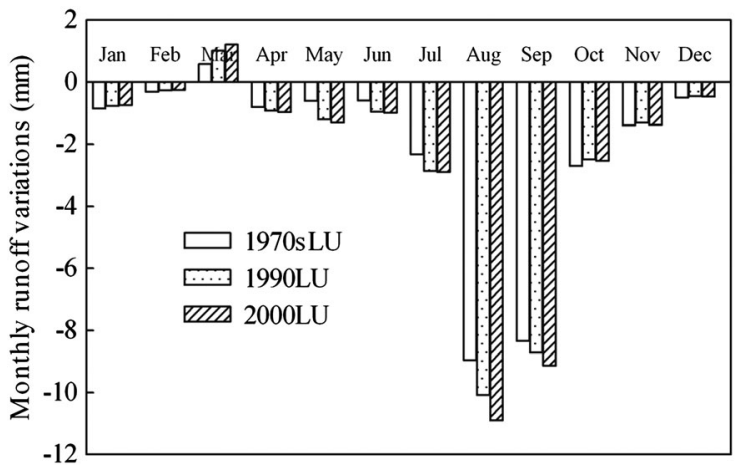

Figure 8. Monthly runoff variations due to changing climate conditions (average-dry) in different land use conditions

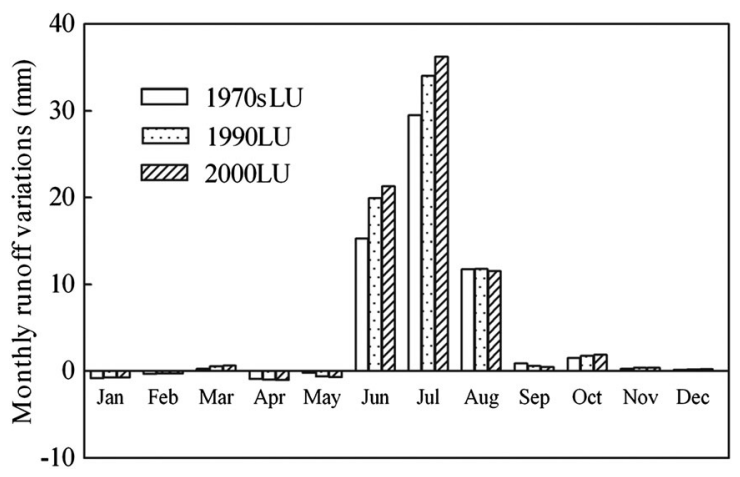

Figure 9. Monthly runoff variations due to changing climate conditions (average-wet) in different land use conditions

average to wet year, a $169.6 \mathrm{~mm}(40.3 \%)$ increase in annual precipitation and a $1.68^{\circ} \mathrm{C}(35.1 \%)$ increase in annual mean air temperature increased the annual runoff by $57.5 \mathrm{~mm}(161.9 \%)$, while the annual runoff decreased by $26.8 \mathrm{~mm}(75.5 \%)$ for a $168.7 \mathrm{~mm}(40.0 \%)$ decrease in annual precipitation and a $1.21^{\circ} \mathrm{C}(25.3 \%)$ increase in annual mean air temperature from the average to dry year (Table VII). Therefore, annual runoff variations due to different climate conditions exceeded and diminished land use change impacts. This result was consistent with the earlier studies that the climatic data (precipitation and air temperature) were the most sensitive input data for runoff variations, while land use was the second of the main boundary condition (Lahmer et al., 2001; Legesse et al., 2003). Furthermore, the annual runoff variation from the average to wet year was more notable than that from the average to dry year, which could be explained by large increase of surface runoff and return flow and relatively low increase of ET from the average to wet year. Additionally, we could see that the increase value in annual precipitation from the average to wet year was almost equal to the decrease value from the average to dry year when the temperature increase was equivalent, but the annual runoff variations for the average-wet year was much higher than that for the average-dry year, showing that precipitation conditions have larger effects on runoff than temperature conditions.

Figure 8 and Figure 9, respectively, indicated monthly runoff variations from the average to dry and wet year. Monthly runoff decreased in all months except March for the average-dry year, and it increased in March and from June to December but decreased from January to May except March for average-wet year. Furthermore, the monthly runoff variations were larger in the wet season than those in the dry season, showing that the effects of changing climate conditions were more remarkable in the wet season, which were primarily caused by large increase or decrease of surface runoff in this season. In the dry season, the smaller change of monthly runoff may be attributed to a sharp decrease of rainfall.

\section{Runoff responses to changing land use and climate conditions}

To examine these effects, we integrated the model with changes in land use and climate conditions and compared the simulations results to that of simulation 1. From the average (1970) to wet (1990) year, changing land use and climate conditions increased the annual runoff by $70.1 \mathrm{~mm}$ (197.4\%) while from the average (1970) to dry (2001) year, the annual runoff decreased by $25.2 \mathrm{~mm}(71.0 \%)$ (Table VII). Monthly runoff responses to changing land use and climate conditions were more distinct in the wet season (Figure 10), which were due to larger changes of surface runoff and return flow caused by relatively plentiful rainfall in the wet season.



Figure 10. Monthly runoff variations due to the combination of changing land use and climate conditions 
Based on the analyzing results above, land use change for three change periods all resulted in annual and monthly runoff increases. However, under the integrated effects of changes in land use and climate conditions, runoff variations from the average to wet year were contrary to those from average to dry year, further illustrating that runoff variations due to changing climate conditions greatly exceeded land use change. This suggested that climate conditions, especially precipitation, were the dominant influencing factor for runoff variations while land use change was secondary. These conclusions were consistent with some previous studies for different climate regions around the world (e.g. Legesse et al., 2003; Guo et al., 2008; Juckem et al., 2008).

\section{Uncertainty analysis}

Because of uncertainties associated with model structure, input, parameter and output, the model prediction is not a certain value and should be represented with a confidence range (Gupta et al., 1998; Beven, 2006; Van Griensven et al., 2008; Yang et al., 2008; Zhang et al., 2009; Shen et al., 2010). In this study, the SWAT model was used to simulate runoff and then, to analyze the impacts of land use on annual and monthly runoff in wet, average and dry years through scenario simulation. Consequently, there were many uncertainties.

First, the SWAT model could simulate runoff processes, and however, it could not realize the pure natural processes due to the conceptual simplification of these processes and the occurrence of unknown anthropogenic processes over the study area. This uncertainty would be expected to be reduced in combination with the observation experiments in the future. Then, the runoff simulation results in this study were very sensitive to climatic input, especially precipitation input, and hence, the relatively few (11) rain gauges and their uneven spatial distribution in the study area greatly affected simulation and analysis results. Thus, more accurate rainfall data might be necessary to obtain more accurate simulated runoff. Third, the uncertainty of calibrated model parameter values had significant effects on runoff simulation due to the non-uniqueness of optimal parameter sets. Furthermore, parameters attained through empirical estimation and optimization of corrected runoff data could not ensure the precision and reliability of the predicted results (Beck, 1987). Fourth, the selection of different precipitation years caused uncertainties for analyzing the effects of land use change on runoff under the wet, average and dry climate conditions. If the year with $P=25 \%, P=50 \%$ and $P=75 \%$ was represented as the wet, average and dry years, respectively, runoff variations caused by land use change in the wet/dry year would decrease but the proportions would increase. For example, land use change from the early 1970 s to 1990 , from 1990 to 2000 and from the early 1970s to 2000 would increase the annual runoff by $9.5 \mathrm{~mm}(20.3 \%)$,
$2.8 \mathrm{~mm}(6.1 \%)$ and $12.4 \mathrm{~mm}(26.4 \%)$ in the wet year and by $5.3 \mathrm{~mm}(27.1 \%), 1.6 \mathrm{~mm}(8.1 \%)$ and $6.9 \mathrm{~mm}$ $(35.2 \%)$ in the dry year. In addition, given a land use condition, runoff variations due to changing climate conditions would also decrease. For example, under the land use condition of the early 1970s, the annual runoff would increase by $11.5 \mathrm{~mm}$ (32.5\%) from the average to wet year and decrease by $15.8 \mathrm{~mm}(44.5 \%)$ from the average to dry year.

\section{CONCLUSION}

The SWAT model was applied to the middle and upstream reaches of Taoerhe River basin, Northeast China, to simulate the effects of land use change on annual and monthly runoff in wet, average and dry years. Model calibration and validation were carried out to determine the most appropriate parameters values and the calibrated SWAT model produced relatively good simulation results at the annual and monthly time scales.

From the early 1970 s to 2000 , land use change occurred over the study area with decreases in forest $(10.6 \%)$, grassland $(4.6 \%)$ and water body $(3.1 \%)$ as well as an increase in farmland (17.0\%). During 1961-2001, the annual runoff had a significant increase, the annual mean air temperature increased $1{ }^{\circ} \mathrm{C}$ in the 1990 s than before 1990 , and the annual precipitation showed a non-significant increasing trend. The long-term monotonic trend was obvious in March, June and July for monthly runoff and was distinct in December for monthly precipitation.

Land use change led to increases in annual and monthly runoff, which was more distinct in the wet year or in the wet season. Climate conditions from the average to wet year caused increases in annual and monthly (March and from June to December) runoff but from the average to dry year, annual and monthly (all months except March) runoff decreased, and these effects were more remarkable in the wet season. When land use and climate conditions simultaneously changed, the annual runoff increased from the average to wet year but decreased from the average to dry year. The monthly runoff variations resulting from the integrated effects of changing land use and climate conditions were more significant in the wet season.

In conclusion, the results of this study showed that climate conditions, especially precipitation, played an important role in runoff variations while the contribution of land use change was secondary. Furthermore, the effects of changes in land use and/or climate conditions on monthly runoff were larger in the wet season.

\section{ACKNOWLEDGEMENTS}

This study is financially supported by the National Natural Science Foundation of China (No. 40571029). We are very grateful to the anonymous reviewers for their helpful comments and suggestions. 


\section{REFERENCES}

Albek M, Ogutveren UB, Albek E. 2004. Hydrological modeling of Seydi Suyu watershed (Turkey) with HSPF. Journal of Hydrology 285 : 260-271.

Arnold JG, Fohrer N. 2005. SWAT2000: current capabilities and research opportunities in applied watershed modeling. Hydrological Processes 19: $563-572$.

Arnold JG, Srinivasan R, Muttiah RS, Williams JR. 1998. Large area hydrologic modeling and assessment. Part I: model development. Journal of the American Water Resources Association 34: 73-89.

Beck MB. 1987. Water quality modeling: a review of the analysis of uncertainty. Water Resource Research 23: 1393-1442.

Beven KJ. 2006. A manifesto for the enquiringly thesis. Journal of Hydrology 320: 18-36.

Bewket W, Sterk G. 2005. Dynamics in land cover and its effect on stream flow in the Chemoga watershed, Blue Nile basin, Ethiopia. Hydrological Processes 19: 445-458.

Chaves JE, Neill C, Germer S, Neto S, Krusche AV, Elsenbeer H. 2008. Land management impacts on runoff sources in small Amazon watersheds. Hydrological Processes 22: 1766-1775.

Costa MH, Bottab A, Cardille JA. 2003. Effects of large-scale changes in land cover on the discharge of the Tocantins River, Southeastern Amazonia. Journal of Hydrology 283: 206-217.

Crokea BFW, Merrittc WS, Jakemana AJ. 2004. A dynamic model for predicting hydrologic response to land cover changes in gauged and ungauged catchments. Journal of Hydrology 291: 115-131.

DeFries R, Eshleman KN. 2004. Land-use change and hydrologic processes: a major focus for the future. Hydrological Processes 18: 2183-2186.

Fohrer N, Haverkamp S, Eckhardt K, Frede H. 2001. Hydrologic response to land use changes on the catchment scale. Physics and Chemistry of the Earth $(B)$ 26: 577-582.

Guo H, Hu Q, Jiang T. 2008. Annual and seasonal stream flow responses to climate and land-cover changes in the Poyang Lake basin, China. Journal of Hydrology 355: 106-122.

Gupta HV, Sorooshian S, Yapo PO. 1998. Toward improved calibration of hydrologic models: multiple and noncommensurate measures of information. Water Resources Research 34(4): 751-763.

Haverkamp S, Fohrer N, Frede HG. 2005. Assessment of the effect of land use patterns on hydrologic landscape functions: a comprehensive GIS-based tool to minimize model uncertainty resulting from spatial aggregation. Hydrological Processes 19: 715-727.

Juckem PF, Hunt RJ, Anderson MP, Robertson DM. 2008. Effects of climate and land management change on streamflow in the driftless area of Wisconsin. Journal of Hydrology 355: 123-130.

Kundzewicz ZW, Mata LJ, Arnell NW, Döll P, Kabat P, Jiménez B, Miller KA, Oki T, Sen Z, Shiklomanov IA. 2007. Freshwater resources and their management. In Climate Change 2007: Impacts, Adaptation and Vulnerability. Contribution of Working Group II to the Fourth Assessment Report of the Intergovernmental Panel on Climate Change, Parry ML, Canziani OF, Palutikof JP, van der Linden PJ, Hanson CE (eds). Cambridge University Press: Cambridge, UK; 73-210.

Lahmer W, Pfiitzner B, Becker A. 2001. Assessment of land use and climate change impacts on the mesoscale. Physics and Chemistry of the Earth (B) 26(7-8): 565-575.

Lee KS, Chung ES. 2007. Hydrological effects of climate change, groundwater withdrawal, and land use in a small Korean watershed. Hydrological Processes 21: 3046-3056.

Legesse D, Vallet-Coulomb C, Gasse F. 2003. Hydrological response of a catchment to climate and land use changes in Tropical Africa: case study South Central Ethiopia. Journal of Hydrology 275: 67-85.

Li LJ, Jiang DJ, Li JY, Liang LQ, Zhang L. 2007. Advances in hydrological response to land use and land cover change. Journal of Natural Resources 22: 211-224 (in Chinese).

Li Z, Liu WZ, Zhang XC, Zheng FL. 2009. Impacts of land use change and climate variability on hydrology in an agricultural catchment on the Loess Plateau of China. Journal of Hydrology 377: 35-42.

Liu CM. 2004. Study of some problems in water cycle changes of the Yellow River basin. Advances in Water Science 15: 608-614 (in Chinese).
Liu JY, Deng XZ, Liu ML, Zhang SW. 2002. Study on the spatial patterns of land-use change and analyses of driving forces in Northeastern China during 1990-2000. Chinese Geographical Science 12: 299-308.

Liu YB, Gebremeske S, Smedt FD, Hoffmann L, Pfister L. 2006. Predicting storm runoff from different land-use classes using a geographical information system-based distributed model. Hydrological Processes 20: 533-548.

Ma X, Xu JC, Luo Y, Aggarwal SP, Li JT. 2009. Response of hydrological processes to land-cover and climate changes in Kejie watershed, South-west China. Hydrological Processes 23: 1179-1191.

Moriasi DN, Arnold JG, Van Liew MW, Bingner RL, Harmel RD, Veith TL. 2007. Model evaluation guidelines for systematic quantification of accuracy in watershed simulations. Transactions of the ASABE 50: 885-900.

Muttiah RS, Wurbs RA. 2002. Scale-dependent soil and climate variability effects on watershed water balance of the SWAT model. Journal of Hydrology 256: 264-285.

Niehoff D, Fritsch U, Bronstert A. 2002. Land-use impacts on stormrunoff generation: scenarios of land-use change and simulation of hydrological response in a meso-scale catchment in SW-Germany. Journal of Hydrology 267: 80-93.

Pohlert T, Huisman JA, Breuer L, Frede HG. 2005. Modeling of point and nonpoint source pollution of nitrate with SWAT in the river Dill, Germany. Advances in Geosciences 5: 7-12.

Romanowicz AA, Vanclooster M, Rounsevell M, Junesse IL. 2005. Sensitivity of the SWAT model to the soil and land use data parametrisation: a case study in the Thyle catchment, Belgium. Ecological Modelling 187: 27-39.

Santhi C, Arnold JG, Williams JR, Srinivasan R, Hauck LM. 2001. Validation of the SWAT model on a large river basin with point and non point sources. Journal of the American Water Resources Association 37: 1169-1188.

Shen ZY, Hong Q, Yu H, Niu JF. 2010. Parameter uncertainty analysis of non-point source pollution from different land use types. Science of the Total Environment 408: 1971-1978.

Shi PJ, Yuan Y, Chen J. 2001. The effect of land use on runoff in Shenzhen City of China. Acta Ecologica Sinica 21(7): 1041-1049 (in Chinese).

Shi XZ, Yu DS, Pan XZ, Sun WX, Gong ZG, Warner ED, Petersen GW. 2002. A framework for the 1:1,000,000 soil database of China. In proceedings of the 17th World Congress of Soil Science, in Bangkok 1757(1-5).

Singh P, Bengtsson L. 2004. Hydrological sensitivity of a large Himalayan basin to climate change. Hydrological Processes 18: 2363-2385.

Sneyers R. 1990. On the statistical analysis of series of observations. WMO Technical Note No. 143, Secretariat of the World Meteorological Organization, Geneva, Switzerland.

Van Griensven A, Meixner T, Srinivasan R, Grunwals S. 2008. Fit-forpurpose analysis of uncertainty using split-sampling evaluations. Hydrological Sciences Journal 53(5): 1090-1103.

Vörösmarty CJ, Green P, Salisbury J, Lammers RB. 2000. Global water resources: vulnerability from climate variability and population growth. Science 289: 284-288.

Wang GX, Liu JQ, Kubota J, Chen L. 2007. Effect of land-use changes on hydrological processes in the middle basin of the Heihe River, Northwest China. Hydrological Processes 21: 1370-1382.

Wang SF, Kang SZ, Zhang L, Li FS. 2008. Modelling hydrological response to different land-use and climate change scenarios in the Zamu River basin of Northwest China. Hydrological Processes 22: 2502-2510.

Wegehenkel M. 2002. Estimating of the impact of land use changes using the conceptual hydrological model THESEUS-a case study. Physics and Chemistry of the Earth 27: 631-640.

Wu KS, Johnston CA. 2007. Hydrologic response to climatic variability in a great lakes watershed: a case study with the SWAT model. Journal of Hydrology 337: 187-199.

Xia J, Tan G. 2002. Hydrological science towards global change: progress and challenge. Resources Science 24: 1-7 (in Chinese).

Yang J, Reichert P, Abbaspour KC, Xia J, Yang H. 2008. Comparing uncertainty analysis techniques for a SWAT application to the Chaohe Basin in China. Journal of Hydrology 358: 1-23.

Zhang XS, Srinivasan R, Bosch D. 2009. Calibration and uncertainty analysis of the SWAT model using genetic algorithms and Bayesian model averaging. Journal of Hydrology 374: 307-317. 